\title{
Phytochemical Screening and Antidiabetic Activity of N-hexane, Ethyl acetate and Water Extract from Durian Leaves (Durio zibethinus L.)
}

\author{
DYNA GRACE ROMATUA ARUAN ${ }^{1,2}$, TONEL BARUS ${ }^{1}$, GINDA HARO $^{3}$, \\ RIKSON SIBURIAN ${ }^{1 *}$ and PARTOMUAN SIMANJUNTAK ${ }^{4,5}$
}

${ }^{1}$ Postgraduate of Chemistry Department, Faculty of Mathematic and Natural Science,

University of Sumatera Utara, Padang Bulan, Medan 20155, Indonesia.

2Department Pharmacy and Public Health, University of Sari Mutiara Indonesia,

Medan 20123, Indonesia.

${ }^{3}$ Department Pharmacy, University of Sumatera Utara, Medan 20155, Indonesia.

${ }^{4}$ Research Centre for Biotechnology, Indonesian Institute of Science, LIPI JI. Raya Bogor Km 46, Cibinong 16911, Indonesia.

${ }^{5}$ Fakultas Farmasi, Universitas Pancasila, Jl. Srengseng Sawah, Jagakarsa, Jakarta, Indonesia. ${ }^{*}$ Corresponding author E-mail: riksonsiburian2000@ yahoo.com

http://dx.doi.org/10.13005/ojc/350166

(Received: September 25, 2018; Accepted: November 10, 2018)

\section{ABSTRACT}

The leaf of Durian (Durio zibenthinus L.) contain flavonoids and steroids in ethanol extract. Natural flavonoids have an important role in the prevention of diabetes and its complications and are able to provide good effects in the fight against diabetes mellitus, either through the ability to reduce glucose absorption and improve glucose tolerance. The purpose of this research is to know the activity of antidiabetic extract of $n$-hexane, ethyl acetate and water from durian leaf ethanol extract. The results of phytochemical screening screen showed that durian leaf contains chemical compounds of flavonoids, steroids, and glycosides. The treatment was gradual to obtain durian leaf extract i.e. with $96 \%$ ethanol, then partitioned gradually with n-hexane and ethyl acetate. Therefore, the extract of $n$-hexane, ethyl acetate and water is obtained. All three extracts were tested activity antidiabetic with inhibition method of $\alpha$-glucosidase enzyme activity. The inhibitory results of $\alpha$-glucosidase enzyme activity showed $\mathrm{IC}_{50}$ values for n-hexane, ethyl acetate and water extracts of $9.79 \mu \mathrm{g} / \mathrm{mL}$; $38.18 \mu \mathrm{g} / \mathrm{mL}$ and $35.83 \mu \mathrm{g} / \mathrm{mL}$. The results show that the polar chemical component of the durian leaf is potential as an antidiabetic.

Keywords: Phytochemistry, Diabetes mellitus, Antidiabetic, Extraction, Flavonoids, Durio zibenthinus L.

\section{INTRODUCTION}

Diabetes mellitus is a metabolic disorder caused by a lack of insulin in a person's body. The lack of insulin in a person's body sugar

This is an Open Access article licensed under a Creative Commons license: Attribution 4.0 International (CC- BY). Published by Oriental Scientific Publishing Company @ 2018

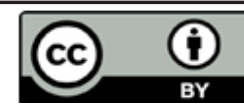


(glucose) consumed by the body cannot be processed perfectly. This situation causes sufferers to experience hyperglycemia or excess blood sugar. In diabetes, excessive blood sugar levels can cause long-term damage, dysfunction and failure of various organs, especially the eyes, kidneys, nerves, heart and blood vessels ${ }^{1}$. How to treat diabetes mellitus is one of them by inhibiting the $\alpha$-glucosidase enzyme. The enzyme has a role in converting carbohydrates to sugar (glucose) can be returned to normal limits ${ }^{2}$. Durian (Durio zibethinus L.) is one of the Malvaceae family plants which has antidiabetic activity on durian skin ethanol extract ${ }^{3}$. Phytochemical screening on Durian fruit contains the chemical compound flavonoids, polyphenols ${ }^{4}$. In the methanol extract durian bark contains flavonoids, alkaloids, tannins, terpenoids, and steroids ${ }^{5}$. The aim of the study was to determine the chemical compounds of durian leaves and to test antidiabetic activity so that it could be developed as a natural medicine.

\section{MATERIALS AND METHODS}

The material used in the study is. Ethanol $96 \%$, n-hexane, ethyl acetate, 1\% DMSO, $0.1 \mathrm{M}$ phosphate buffer and $0.01 \mathrm{M}, 0.5 \mathrm{mM}$ p-nitrophenyl$\alpha$-D-glucosidase substrate, $0.04 \alpha$-glucosidase enzyme / mL, $\mathrm{Na}_{2} \mathrm{CO}_{3} 0.2 \mathrm{M}$, distilled water.

Research Methods. Sample drying cabinet, simplicia grinder, set of distillation apparatus, rotary evaporator, Ultraviolet-Visible Spectrophotometer (Hitachi U-3900H), micropipette, tip, measuring cup, measuring flask, analytic scale, incubator (Jouan), and a set of glass tools.

Phytochemical Screening. Identification flavonoids. $10 \mathrm{~g}$ each extract, dissolved $100 \mathrm{~mL}$ hot water, boiled for $5 \mathrm{~min}$ and filtered in hot condition, into $5 \mathrm{~mL}$ of filtrate added $0.1 \mathrm{~g}$ of magnesium powder and $1 \mathrm{~mL}$ of concentrated hydrochloric acid and $2 \mathrm{~mL}$ of amyl alcohol, shaken and allowed to separate. Flavonoids positive if there is a red or yellow or orange color in the amyl alcohol layer ${ }^{6}$ Identification saponins. The extract was weighed as much as $0.5 \mathrm{~g}$ and put into a test tube, then added $10 \mathrm{~mL}$ of hot water, cooled, then shaken vigorously for 10 minutes. If foam is formed as high as 1-10 $\mathrm{cm}$ that is stable not less than $10 \mathrm{~min}$ and the foam does not disappear with the addition of 1 drop of
$2 \mathrm{~N}$ hydrocloride acid indicating the presence of saponins. ${ }^{7}$

Identification tanins. A total of $1 \mathrm{~g}$ of extract was weighed, along with $10 \mathrm{~mL}$ of distilled water and then filtered, the filtrate was diluted with water until colorless. The solution was taken as much as $2 \mathrm{~mL}$ and added 1-2 drops of iron (III) chloride reagent. If there is a blue or blackish green color indicates the presence of tannins.

Identification alkaloids. The weighed extract was $0.5 \mathrm{~g}$ then added $1 \mathrm{~mL}$ of $2 \mathrm{~N}$ hydrochloride acid and $9 \mathrm{~mL}$ of distilled water, heated on a water bath for 2 min cooled and filtered. The obtained filtrate is used for alkaloid tests. Three test tubes are taken, then put $0.5 \mathrm{~mL}$ of filtrate in to it. In each test tube added 2 drops mayer reagents, 2 drops Wagner reagent, Dragendorff reagent. Alkaloids are positives if there is sediment or turbidity in two of the three experiments above.

Identification glycosides. A total of 3 gram extract added $30 \mathrm{~mL}$ of ethanol : water (7:3) refluxed for $10 \mathrm{~min}$ cooled and filtered. Then $20 \mathrm{~mL}$ of filtrate was taken with $25 \mathrm{~mL}$ of distilled water and $25 \mathrm{~mL}$ of lead (II) acetate $0.4 \mathrm{M}$, shaken, allowed to stand for $5 \mathrm{~min}$ then filtered. The filtrate was added $20 \mathrm{~mL}$ of a mixture of chloroform and isopropanol (3:2), repeated three times. Then evaporated at a temperature of not more than $50^{\circ} \mathrm{C}$. the rest is dissolved in $2 \mathrm{~mL}$ of methanol. The remaining solution is used for experiments: as much as $0.1 \mathrm{~mL}$ if the experimental solution is put into a test tube and evaporated over a water bath. The remaining $2 \mathrm{~mL}$ of water and added 5 drops of Molish reagent. Then added $2 \mathrm{~mL}$ of sulfuric acid through the tube wall with slowly. Forming a purple ring at the boundary of the two liquids, indicating the presence of a sugar bond.

Identification steroids/terpenoids. The extract was weighed as much as $1 \mathrm{~g}$ macerated with $20 \mathrm{~mL}$ of $\mathrm{n}$-hexane for $2 \mathrm{~h}$ filtered. The filtered was evaporated in a vaporized plate and the remaining LiebermannBurchard reagent was added through the cup wall. If a purple or red color turns blue or blue or green blue indicates the presence of triterpenoids/steroids.

Inhibition of the enzyme $\alpha$-glucosidase. Tests were carried out based on ${ }^{8}$ with a phosphate buffer $0.1 \mathrm{M} \mathrm{pH} 7.0$ as much as $50 \mu \mathrm{L}$ added $25 \mu \mathrm{L}$ 
$0.5 \mathrm{mM}$ 4-nitrophenyl $\alpha$-D-glucopyranose. The mixture was brokububated for $5 \mathrm{~min}$ at a temperature of $37^{\circ} \mathrm{C}$ and then added $10 \mu \mathrm{L}$ of the tested sample. Extracts were made with varying concentrations of $5 \mathrm{ppm}, 10$ ppm, 25 ppm, 50 ppm, and 100 solutions were added $250 \mu \mathrm{L}$ of $\alpha$-glucosidase solution, incubated for $30 \mathrm{~min}$ at $37^{\circ} \mathrm{C}$. The solution is terminated with the addition of $1000 \mu \mathrm{L}$ of $0.2 \mathrm{M} \mathrm{Na}_{2} \mathrm{CO}_{3}$ solution. The inhibition of the extract is measured on $\lambda 410 \mathrm{~nm}$ with microplate reader. The experiment was carried out in triplo

\section{RESULTS AND DISCUSSION}

The leaves of durian $7 \mathrm{~kg}$, drying in room temperature, and cut small, then made powder. We got the powder of leaves durian $4,8 \mathrm{~kg}$. The powder was maceration with ethanol $96 \%$. We got the ethanol extract 185,2 gram. Phytochemical screening results is done in maceration for $2 \times 24$ hours. Extraction is filtered to separate the filtr ate from the residue. The residue is remacerated until the obtained filtrate does not contain flavonoids. The maceration filtrate was evaporated using a rotary evaporator to obtain ethanol extract of Durian leaf ${ }^{9}$. In ethanol extract, n-hexane and water were added (1:1), then the extract was filtered, and the n-hexane filtrate was evaporated. Ethyl acetate is added to the water extract, then filtered and evaporated from ethyl acetate and water extraction. Then each extract, namely $n$-hexane, ethyl acetate, and water extract, was screened for phytochemical screening and antidiabetic testing. Phytochemical screening screening for Durian (Durio zibethinus L.) leaves includes examination of secondary metabolite compounds such as alkaloids, saponins, flavonoids, tannins, glycosides, and terpenoids/steroids ${ }^{7}$ described in Table 1.

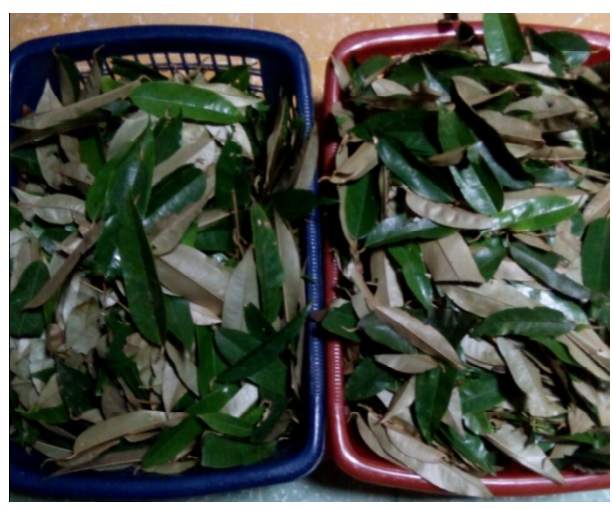

Fig. 1. Leaves of Durian
Table 1: Phytochemical Screening of Durian (Durio zibethinus L.) leaves

\begin{tabular}{lccccc}
\hline No & Metabolite & Ethanol & n-Hexane Water & Ethyl acetate \\
\hline 1 & Alkaloids & - & - & - & - \\
2 & Saponins & - & - & - & - \\
3 & Flavonoids & + & - & - & + \\
4 & Tannins & - & - & + & - \\
5 & Terpenoids/Steroids & + & + & - & + \\
6 & Glycosides & + & - & + & + \\
\hline
\end{tabular}

\section{Antidiabetic Activity}

Preliminary test and inhibition of the enzyme $\alpha$-glucosidase is the hydrolysis of the enzyme against $p$-nitrophenyl- $\alpha-D$-glucopyranoside to $p$-nitrophenol which gives a yellow color ${ }^{10}$. The enzyme inhibitory activity test was carried out by spectropotometry method at a wavelength of $410 \mathrm{~nm}$. This test was carried out at different extract concentrations to determine the effect of the concentration of each extract on $\mathrm{IC}_{50}$ inhibitory power, the greater the percent value indicated, the greater the inhibition of the enzyme, and vice versa. $I_{50}$ values showed the ability of the extract to inhibit enzyme activity by $50 \%$. The $I_{50}$ value $<50 \mu \mathrm{g} / \mathrm{mL}$ is very strong, if the value of $50-100 \mu \mathrm{g} / \mathrm{mL}$ is said to be strong, if the value of $100-150 \mu \mathrm{g} / \mathrm{mL}$ is said to be weak, the value of $150-200 \mu \mathrm{g} / \mathrm{mL}$ is said to be very weak if the smaller $\mathrm{IC}_{50}$ value indicates activity higher inhibition, and vice versa. The results of this study indicate that the $I_{50}$ value of each extract of $n$-hexane, ethyl acetate and water is $35.83 \mu \mathrm{g} / \mathrm{mL} ; 38.18 \mu \mathrm{g} / \mathrm{mL}$; and $9.79 \mu \mathrm{g} / \mathrm{mL}$. This shows that water extract has the potential as a source of active chemical compounds for diabetic drugs which are polar compounds.

Table 2: Test results for Antidiabetic Activity of $\mathbf{n}$-Hexane, Ethyl acetate, and Water extract of Durian (Durio zibethinus L.) leaves with inhibition method of $\alpha$-glucosidase enzyme activity

\begin{tabular}{lccc}
\hline Extracts & $\begin{array}{c}\text { Concentration } \\
(\mathrm{ppm})\end{array}$ & $\begin{array}{c}\text { Inhibition } \\
(\%)\end{array}$ & $\begin{array}{c}\mathrm{IC}_{50} \\
(\mathrm{ppm})\end{array}$ \\
\hline Water Extract & 5 & 227,882 & 97,889 \\
& 10 & 522,063 & \\
& 25 & 565,974 & \\
& 50 & 610,317 & \\
Ethyl acetate Extract & 100 & 625,027 & \\
& 5 & 227,666 & 38.1772 \\
& 10 & 271,793 & \\
& 25 & 316,136 & \\
358,300 & 50 & 632,057 & \\
& 100 & 668,937 & \\
& - Hexane Extract & 5 & 139,411 \\
& 10 & 389,682 & \\
& 25 & 433,809 & \\
& 50 & 595,392 & \\
\hline
\end{tabular}




\section{CONCLUSION}

Phytochemical screening results showed that secondary metabolites such as flavonoids, terpenoids/steroids, glycosides, existed in Durio zibethinus $L$. durian leaves. The results showed that antidiabetic activity in Durian leaf water extract was very strong because $\mathrm{IC}<50 \mathrm{ppm}$ was $9.7889 \mathrm{ppm}$ compared with $n$-hexane and ethyl acetate extract of Durian leaves.

\section{ACKNOWLEDGMENT}

The author would like to thank Ministry of Research, Technology and Higher Education (RISTEKDIKTI) for providing research funds through the BPPDN program in 2015, Phytochemical Laboratory of the Faculty of Pharmacy, University of North Sumatera and the Research Center for Biotechnology, Indonesian Institute of Science (LIPI) Cibinong for the use of laboratories to test Antidiabetic activity

\section{REFERENCES}

1. Herliana, E. Diabetes correction by herbs. First Print. FMedia., 2013, 1.

2. Bosenberg, L. H. The mechanism of action of oral antidiabetic drugs: a review of recent literature. The Journal of Endocrinology, Metabolism and Diabetes of South Africa, 2011, 13(3), 80-88.

3. Toledo, F., Patricia Arancibia-Avila, YongSeo Park. Screening of The Antioxidant and Nutritional Properties, phenolic contents and proteins of five durian cultivars. International Journal of Food Sciences and Nutrition. Departmen of Medicinal Chemistry and Natural Products, School of Pharmacy. The Hebrew University, Jerusalem, Israel., 2008, 415-427.

4. Muhtadi, Primarianti AU, Sujono TA. Antidiabetic and Antihypercholesterolemia Activites of Rambutan (Nephelium lappaceium L.) and Durian (Durio zibethinus Murr.) Fruit Peel Extracts. Journal of Applied Pharmaceutical Science., 2016, 6(04), 190-194.

5. Setyowati WAE, Ariani SRD, Ashadi, Mulyani B, Rahmawati CP. Phytochemical Screening and Identification of the Main Components of Durian Skin Methanol Extract (Durio zibethinus L.) Varietas Petruk. Proceedings of the National Seminar on Chemistry and Chemical Education VI. Chemistry Education Study Program Department of FMIPA FKIP UNS. Surakarta., 2014 June 21.

6. Fransworth, N.R., Biological and Phytochemical Screening of Plants, Journal of Pharmaceutical Sciences., 1996, 55(3), 2226-227.

7. Harborne JB., Phytochemical Method, Bandung, ITB, 1987.

8. Saijo, A-glucosidase Inhibitor from Bergenia Ligulata., J. of Oleo Sciences., 2008, 57(8), 431-435.

9. Republic of Indonesia Ministry of Health, General Standard Parameters of Medicinal Plant Extracts, Jakarta., 2000.

10. Hardoko, Febriani A., Sirantantri T., Antidiabetic Activity in In Vitro Agar, And Agaropectin from Gracilaria gigas Seaweed. Indonesian Fisheries Product Processing Journal., 2015, 18(2), 128-139 